\title{
Future Solvency Prediction for Property Insurance Companies
}

\author{
Min Le \\ School of Insurance, \\ Central University of Finance and Economics, \\ Beijing, China \\ Jingfeng Xu \\ School of Insurance, \\ Central University of Finance and Economics, \\ Beijing, China
}

\begin{abstract}
The service period of insurance products is often a period of time after purchasing products. Therefore, using the existing information to assess the future solvency of the insurance company is very important to the policyholders' insurance purchase decision and equivalently important to the operation of the insurance companies. Our research sets up a model to predict the solvency of the property insurance companies in the coming year, focusing on whether the two indexes of the company size and the current solvency adequacy ratio are strong and reliable, and to provide support for policyholders' insurance purchase decisions. We show that, contrary to the conventional thought that big companies are more solvent, company size has a negative impact on its future solvency. And the current solvency adequacy ratio is a reliable index to predict the future solvency so that our research results also indicate the regulatory supervision of solvency is beneficial to take action to protect the interests of the policyholders as soon as possible.
\end{abstract}

Keywords: Future Solvency; Prediction; Property Insurance; Policyholder

\section{INTRODUCTION}

Solvency is of great importance to all participants in the insurance market, including insurance regulators, policyholders, agents and insurance companies [1]. As insurance products become more and more familiar to the public, consumers' willingness to buy insurance is strengthened. However, since the service period of insurance products happens after the purchase of products, consumer is very concerned about whether the insurance company will be able to pay in the future when purchasing products of insurance company. Assessing the solvency of an insurance company in the future during the product service period is very important to the policyholder's purchase decision, and equivalently important to the operation of the insurance company.

Is it right that policyholders often have a habit of thinking that large companies are more solvency-guaranteed? When assessing the solvency of insurance companies, regulators of various countries usually use their own defined solvency adequacy ratio indicators to require insurance companies to maintain a certain solvency adequacy ratio and disclose it publicly. Can the current solvency adequacy ratio be a reliable indicator for policyholders to measure and predict the future solvency of insurance companies?

Just as the deterioration process of the financial situation of the general enterprise, the deterioration process of the solvency of the insurance company is also with time continuity 
and cumulative variability. Therefore, Solvency crises are not a sudden change process, and can be used to predict future solvency with current information.

In this research, based on the solvency adequacy ratio data and other information disclosed by insurance companies, we can predict the solvency of property insurance companies for one year in advance, focusing on the two indicators, the size of the company and the current solvency adequacy ratio, is strong and reliable, and to provide support for policyholders' insurance purchase decisions-making next year. Property insurance company's products are usually short-term products within one year, so predicting its solvency one year in advance is enough to support policyholders' purchase decisions.

We find that, contrary to the conventional thought of policyholders who often think that large companies are more solvency-guaranteed, firm size has a negative impact on future solvency. The current solvency adequacy ratio is a reliable indicator of future solvency of insurance companies. The prediction model that excludes the current solvency adequacy ratio is much less explanatory.

Our research shows the following three contributions. Firstly, most of the existing studies focus on the current solvency, but few on the future solvency. This paper enriches this kind of research; secondly, our research provides help for policyholders to choose insurance companies when they buy insurance products. Thirdly, the results support the view that insurance regulation is effective and that the regulation of solvency by the regulator is helpful for early actions to protect the interests of consumers.

The rest of this research is arranged as follows: The second part is literature review; the third part describes the sample selection and model design, in which we define the forecasting indicators and have descriptive statistical analysis. The following part presents our results, and finally comes to the conclusion.

\section{LITERATURE REVIEW}

Most of the early studies on the solvency of insurance companies focused on the insurance market of developed countries such as the United States, and directly used bankruptcy as a representative indicator of the solvency and financial strength of insurance companies. In the absence of an insurance company bankruptcy in China, these studies are not suitable for our analysis. Chen and Wong [2] analyze the financial strength of insurance companies in Japan, Malaysia, Singapore and Taiwan, using the solvency of the insurer as a dependent variable rather than bankruptcy, because there were no bankrupt insurance companies in these countries other than Japan. Rauch and Wende [3] design a forecasting model for German insurance companies to predict the future solvency adequacy rate of insurance companies using two-year lag in solvency adequacy rate and other information. However, foreign solvency forecasting models are not necessarily applicable to China because of the different market environment and insurance companies' characteristics in different countries.

Most empirical studies on solvency in China focus on the factors influencing current solvency [4-6]. On this basis, there are also some studies about the early-warning and prediction of solvency [7-8]. However, most of them still take current solvency as the research object, and there are few studies on forecasting future solvency [9]. Based on the data of insurance companies in China from 2001 to 2003, C. Lv et al. [9] forecast the deteriorating solvency of insurance companies by using multiple discriminant analysis model and Logit model 1 to 2 years in advance, and conclude that there is no obvious difference between the predictive ability of multiple discriminant analysis model and Logit model. 
To sum up, our research mainly improves the existing research in the following aspects.

- Based on the data of China's insurance companies, this study takes solvency adequacy ratio as a measure of solvency status, enriches the researches on emerging insurance markets lacking bankruptcy samples, and predicts future solvency, which is different from the existing empirical researches on vast majority of current solvency capacity in China.

- Empirical studies on solvency of Chinese insurance companies mostly use Logit/Logistic model as analytical tool, and need comparative samples with sufficient and insufficient solvency. However, the number of insufficient solvency samples is small, so it can only be processed by various methods [7]. Therefore, this study uses the nature logarithm of solvency adequacy ratio as multiple regression model of dependent variable to avoid the impact of sample processing.

- In the early development of China's insurance industry, information disclosure was inadequate and data collection was difficult. Some existing studies using solvency adequacy ratio as a measure of solvency can only use estimates [5]. The solvency adequacy rate data used in this study is later, and collected manually from the official website of each company, the data is more reliable.

- This study introduces the current annual solvency adequacy ratio in the forecast indicators. Since the deterioration of solvency is a process of time continuity and cumulative variability, the current annual solvency adequacy rate is a reliable indicator to measure the future solvency adequacy rate of insurance companies. Rauch and Wende [3] have confirmed this with data from German property insurance companies, but it is rare to use this as a predictor in similar studies, especially in China.

\section{Sample selection}

\section{SAMPLE SELECTION AND MODEL DESIGN}

We use company-level data from the "China Insurance Yearbook" and the official websites of property insurance companies in China. As China's second generation solvency regulatory framework C-ROSS has been in operation since 2016, this study analyzes the data before CROSS considering the availability and continuity of data. We drop unreliable data and extreme data. Our final sample consists of 192 observations from 2011 to 2015.

\section{Prediction model for future solvency of property insurance companies Basic idea of future solvency prediction model design}

According to the regulations of the China Insurance Regulatory Commission (CIRC), the solvency of an insurance company refers to the ability of an insurance company to repay its debts and takes the solvency adequacy ratio as a quantitative indicator of the supervision of solvency. Solvency adequacy ratio, the ratio of the insurer's actual capital to the minimum capital, requires assurance that it is not less than $100 \%$.

Based on the solvency adequacy ratio of 49 property insurance companies selected for analysis in 2015, the scatter plot is drawn (73 property insurance companies in 2015). The abscissa is the insurance company, and the ordinate is the solvency adequacy ratio.

From Fig. 1 (in order to display the scatter plot more clearly, the point with solvency adequacy ratio more than $900 \%$ is deleted) it can be seen that the solvency adequacy ratio of property insurance companies is mostly between $200 \%$ and $300 \%$ in 2015 , and all of them are above $100 \%$. According to the solvency supervision requirements, these property insurance companies have sufficient solvency. Without sufficient and insufficient comparative samples, Logit/Logistic model is not suitable for our analysis. 


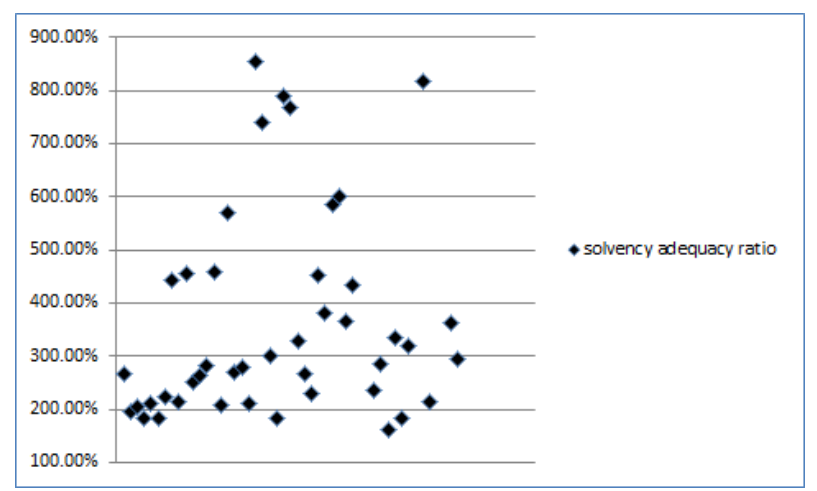

Figure 1 Scatter diagram of solvency adequacy ratio in 2015

Therefore, considering the characteristics of China's property insurance companies and reviewing the existing literature, the basic idea of the model design in this paper is to take solvency in year $t+1$ as the dependent variable, and t-period company size, $t$-period solvency and other t-period variables which may affect the future solvency of property insurance companies as independent variables. We use ordinary least squares (OLS) regressions for each year separately.

It follows Rauch and Wende [3] that cross-sectional data rather than panel data models are chosen for analysis. Because sample selection includes companies of all sizes, we suspect that the standard errors to be heteroscedastic. Therefore, we use robust standard errors for our estimation.

\section{Variable selection and definition Dependent variable}

We use the solvency adequacy ratio defined by CIRC as the representative index of solvency of insurance companies. Therefore, the dependent variable is defined as the nature logarithm of solvency adequacy ratio in year $t+1$. Using the nature logarithm of solvency adequacy ratio is due to the solvency adequacy ratio skewed to the right [10].

\section{Independent variable}

The deterioration of solvency is not a sudden change, but a process with time continuity and cumulative variability. Kramer [11] shows that previous solvency has a significant relationship with the current financial strength of insurance companies. Rauch and Wende [3] confirm that the current solvency adequacy rate is a reliable indicator to measure the future solvency adequacy rate of insurance companies, even during the financial crisis. In this paper, the tperiod solvency adequacy ratio is taken as the representative index of the current solvency, and it also is in the form of nature logarithm.

Some studies [9] believe that large-scale companies are more mature, have the advantages of economies of scale, and have abundant cash flow, so they are strong solvency. But at the same time, we should also take into account large companies have a large business scale and take a large overall risk. A little fluctuation of profit margin may lead to deterioration of solvency. Indicators used to measure the size of a company can use total assets, total revenue, etc. We define it as the nature logarithm of total assets.

Based on the calculation method of solvency adequacy ratio in China before C-ROSS (the data period is 2011-2015 for which C-ROSS has not yet been implemented) and the existing similar research [2-9], we choose other t-period variables that may affect the future solvency of property insurance companies as other explanatory variables to be in the model from the 
aspects of the profitability and corresponding risk level that affect the future actual capital and future minimum capital of insurance companies, in addition to the above two independent variables.

\section{Profitability of short-term investment business}

In the short run, the difference between the profitability of investment business of insurance companies mainly comes from the proportion of assets with high risk of short-term investment, that is, financial assets for sale purposes. Therefore, our research uses the percentage of trading financial asset and financial assets available for sale in assets to represent the profitability of short-term investment business.

\section{Profitability of undertaking business}

Undertaking business is the most important source of profit for property insurance companies. The profit of undertaking business affects the actual capital, but at the same time, the risk of undertaking business also affects the minimum capital. In order to better reflect the impact of these two aspects, we choose the growth rate of self-retained premium as a measure of profitability of the underwriting business.

China's insurance industry is booming, and companies are implementing positive development strategies. But if insurance companies increase premium income and market share by underpricing and other means to bear considerable risks, they must bear adverse financial consequences in the short term, even if the strategy may be worthwhile in the long run.

The combined ratio is another index which reflects the profitability of the undertaking business. The higher combined ratio indicates that the insurance company's business quality is not high under the same scale, which is difficult to improve in the short term. It can be predicted that it will lead to the decline of the solvency in the future.

\section{Overall profitability}

From different perspectives, we choose three indicators: return on assets, operating leverage and growth rate of owner's equity as the representative indicators of overall profitability. Generally speaking, the higher the return on assets indicates that the insurance company has a better level of operation, a higher overall profitability and a better solvency in the future. ROA, refers to the ratio of net profit to assets, is a common index for return on assets.

The use of higher operating leverage ratio indicates that the active sales strategy of property insurance companies means stronger business ability, but the excessive use of leverage makes the company bear greater solvency pressure under the same level of profitability.

The operating leverage ratio refers to the ratio of retained premium to paid-in capital in our research. Owner's equity is the foundation of company's establishment and operation, and the last barrier to prevent insolvency. Its high growth rate means that the actual capital used for repayment will have a relatively more sufficient trend in the future.

The specification of the model is as follows :

$$
Y=c+\alpha_{1} X 1+\alpha_{2} X 2+\alpha_{3} X 3+\alpha_{4} X 4+\alpha_{5} X 5+\alpha_{6} X 6+\alpha_{7} X 7+\alpha_{8} X 8+\varepsilon
$$

Among them, $\alpha_{1}, \alpha_{2}, \alpha_{3}, \alpha_{4}, \alpha_{5}, \alpha_{6}, \alpha_{7}$ and $\alpha_{8}$ are the influence coefficients of the corresponding independent variables. And $\varepsilon$ is the disturbance term in year $t+1$, so it is not related to X1, X2, X3, X4, X5, X6, X7, X8. The definitions of independent variables and their 
correlation with dependent variable are shown in Table 1. In our analysis, we consider the multicollinearity of the variables, but because the VIF is not high, we ignore the multicollinearity aspects.

Table 1 The definitions of independent variables and their correlation prediction with dependent variable

\begin{tabular}{|c|l|c|}
\hline variable & \multicolumn{1}{|c|}{ Definition of independent variables (in year t) } & $\begin{array}{c}\text { Correlation } \\
\text { prediction }\end{array}$ \\
\hline $\mathrm{X} 1$ & Nature logarithm of solvency adequacy ratio & + \\
\hline $\mathrm{X} 2$ & Nature logarithm of total assets & $+/-$ \\
\hline $\mathrm{X} 3$ & $\begin{array}{l}\text { Percentage of trading financial asset and financial } \\
\text { assets available for sale in assets }\end{array}$ & $+/-$ \\
\hline $\mathrm{X} 4$ & Growth rate of self-retained premium & $+/-$ \\
\hline $\mathrm{X} 5$ & Combined ratio & + \\
\hline $\mathrm{X} 6$ & Return on assets (ROA) & $+/-$ \\
\hline$X 7$ & Operating leverage ratio & + \\
\hline$X 8$ & Growth rate of owner's equity & \\
\hline
\end{tabular}

\section{Summary statistics}

\section{RESULTS}

Table 2 shows summary statistics for the variables used in regression analysis. In our sample, the mean of the nature logarithm of solvency adequacy rate in 2013 was the lowest, 1.271, and the corresponding solvency adequacy rate was $356.44 \%$. The average proportion of risky assets in short-term investment has been around $20 \%$ for four years, and the average assets has increased slightly year by year, with little change. The premium growth rate in 2012 is the highest, while the average combined ratio in 2013 is the highest. The average ROA of each year is negative number, the average operating leverage rate has increased year by year, while the average growth rate of owner's equity has rebounded slightly after falling to the lowest level in 2013.

Table 2 summary statistics for the variables

\begin{tabular}{|c|c|c|c|c|c|c|c|c|c|}
\hline$t+1=2015$ & $\mathbf{Y}$ & $\mathrm{X} 1$ & $\mathrm{X} 2$ & X3 & X4 & X5 & X6 & X7 & $\mathrm{X8}$ \\
\hline Mean & 1.365 & 1.331 & 8.330 & 0.218 & 0.184 & 0.567 & -0.003 & 2.255 & 0.268 \\
\hline Max & 3.582 & 3.663 & 12.810 & 0.605 & 2.424 & 0.973 & 0.108 & 21.259 & 3.888 \\
\hline Min & 0.476 & 0.484 & 5.577 & 0.000 & -0.404 & -0.021 & -0.160 & 0.087 & -0.615 \\
\hline Obs & 49 & 49 & 49 & 49 & 49 & 49 & 49 & 49 & 49 \\
\hline$t+1=2014$ & $Y$ & X1 & $\mathrm{X} 2$ & $\mathrm{X3}$ & $\mathrm{X4}$ & X5 & X6 & X7 & $\mathrm{X8}$ \\
\hline Mean & 1.331 & 1.271 & 8.174 & 0.195 & 0.299 & 0.662 & -0.017 & 2.204 & 0.143 \\
\hline Max & 3.663 & 3.653 & 12.674 & 0.645 & 1.539 & 1.290 & 0.084 & 21.821 & 4.582 \\
\hline Min & 0.484 & 0.135 & 5.485 & 0.000 & -0.249 & 0.199 & -0.259 & 0.113 & -0.346 \\
\hline Obs & 49 & 49 & 49 & 49 & 49 & 49 & 49 & 49 & 49 \\
\hline$t+1=2013$ & $\mathbf{Y}$ & X1 & $\mathrm{X} 2$ & $\mathrm{X} 3$ & X4 & X5 & X6 & X7 & $\mathrm{X8}$ \\
\hline Mean & 1.271 & 1.601 & 7.996 & 0.186 & 0.725 & 0.594 & -0.004 & 1.982 & 0.288 \\
\hline Max. & 3.653 & 3.716 & 12.579 & 0.530 & 8.697 & 1.028 & 0.267 & 17.904 & 4.038 \\
\hline Min. & 0.135 & 0.278 & 5.422 & 0.000 & -0.404 & 0.214 & -0.310 & 0.127 & -0.717 \\
\hline Obs & 49 & 49 & 49 & 49 & 49 & 49 & 49 & 49 & 49 \\
\hline$t+1=2012$ & $\mathbf{Y}$ & X1 & $\mathrm{X} 2$ & X3 & X4 & X5 & X6 & X7 & X8 \\
\hline Mean & 1.517 & 1.520 & 7.936 & 0.205 & 0.425 & 0.529 & -0.011 & 1.862 & 0.875 \\
\hline Max. & 3.716 & 4.039 & 12.490 & 0.747 & 2.488 & 0.831 & 0.156 & 13.245 & 6.589 \\
\hline Min. & 0.278 & -0.654 & 5.732 & 0.000 & -0.452 & 0.146 & -0.162 & 0.095 & -0.684 \\
\hline Obs & 45 & 45 & 45 & 45 & 45 & 45 & 45 & 45 & 45 \\
\hline
\end{tabular}




\section{Regression results}

Table 3 shows the regression results of each year. The R2 as high as $0.723,0.745,0.816$ and 0.844 indicates that this is a good prediction model, so policyholders can use the model to evaluate the solvency of property insurance companies in the next year. We find that the current solvency adequacy ratio is the most significant predictor of future solvency adequacy ratio at $1 \%$ level in all years. Compared with other forecasting indicators, the current solvency adequacy ratio has the greatest impact on future solvency and is also the most reliable. Therefore, the solvency adequacy rate required by the CIRC is a reliable index when the policyholders consider the future solvency of property insurance companies when buying insurance products.

Table 4 further supports this assumption, which shows the regression results after removing the current solvency adequacy ratio from the model. It can be seen that the adjusted R2 decreases significantly, which means that the explanatory power of the model removing the current solvency adequacy ratio is greatly reduced.

Table 4 and Table 3 show that, excluding the current solvency adequacy index, the estimated coefficient of the company size index is negative in each year and has passed the 1\% significance test, which shows that the company size has a negative impact on the future solvency, which is compared with the insured who often think that large companies are more solvency insurance. The inertial thinking of obstacles is the opposite.

The ratio of risky assets in short-term investment also has a negative impact on future solvency, which may be related to the poor performance of China's securities investment in 2011-2014, and the return on assets index has a positive impact on future solvency as expected. In the model including the current solvency adequacy ratio index, the company size index coefficient and the return on assets index coefficient are not significant, and the shortterm investment risk assets ratio index coefficient is only significant in 2013, which means that these three indicators have no direct impact on future solvency, but indirectly affect future solvency by influencing current solvency.

In addition, Table 3 also shows that the growth rate of premium has a negative impact on future solvency, indicating that insurance companies increase premium income and market share by assuming considerable risks, thus reducing solvency in the short term, at the same time, the combined ratio also has a negative impact on solvency, which further illustrates that the solvency of insurance companies will deteriorate in the future if they pay attention to the quantity of business but not to the quality of business. 
Table 3 Regression results

\begin{tabular}{|c|c|c|c|c|c|c|}
\hline & \multicolumn{3}{|c|}{$t+1=2012$} & \multicolumn{3}{|c|}{$t+1=2013$} \\
\hline & Coe. & S.E. & & Coe. & S.E. & \\
\hline $\mathrm{X} 1$ & 0.584 & 0.113 & $* * *$ & 0.950 & 0.096 & $* * *$ \\
\hline $\mathrm{X} 2$ & -0.053 & 0.048 & & -0.002 & 0.046 & \\
\hline X3 & -0.043 & 0.522 & & -0.731 & 0.304 & $* *$ \\
\hline $\mathrm{X} 4$ & -0.009 & 0.004 & $* *$ & -0.104 & 0.055 & $*$ \\
\hline $\mathrm{X} 5$ & 0.383 & 0.423 & & -0.380 & 0.241 & $*$ \\
\hline X6 & 0.754 & 1.872 & & 0.323 & 0.952 & \\
\hline $\mathrm{X7}$ & -0.024 & 0.025 & & 0.013 & 0.010 & \\
\hline $\mathrm{X} 8$ & -0.039 & 0.074 & & -0.005 & 0.039 & \\
\hline $\mathrm{R} 2$ & \multicolumn{3}{|c|}{0.745} & \multicolumn{3}{|c|}{0.844} \\
\hline \multirow[t]{3}{*}{ Adjusted R2 } & \multicolumn{3}{|c|}{0.688} & \multicolumn{3}{|c|}{0.812} \\
\hline & \multicolumn{3}{|c|}{$t+1=2014$} & \multicolumn{3}{|c|}{$t+1=2015$} \\
\hline & Coe. & S.E. & & Coe. & S.E. & \\
\hline $\mathrm{X} 1$ & 0.678 & 0.108 & $* * *$ & 0.619 & 0.131 & $* * *$ \\
\hline $\mathrm{X} 2$ & -0.052 & 0.044 & & -0.072 & 0.040 & $*$ \\
\hline X3 & -0.089 & 0.289 & & -0.325 & 0.447 & \\
\hline $\mathrm{X} 4$ & 0.106 & 0.172 & & 0.012 & 0.200 & \\
\hline $\mathrm{X} 5$ & -0.049 & 0.015 & $* * *$ & -0.009 & 0.264 & \\
\hline $\mathrm{X} 6$ & 2.213 & 1.825 & & 2.298 & 2.324 & \\
\hline $\mathrm{X} 7$ & 0.032 & 0.016 & $* *$ & -0.005 & 0.015 & \\
\hline $\mathrm{X} 8$ & 0.231 & 0.066 & $* * *$ & -0.046 & 0.057 & \\
\hline $\mathrm{R} 2$ & \multicolumn{3}{|c|}{0.816} & \multicolumn{3}{|c|}{0.723} \\
\hline Adjusted R2 & \multicolumn{3}{|c|}{0.780} & \multicolumn{3}{|c|}{0.647} \\
\hline
\end{tabular}

*, ** and ${ }^{* * *}$ denote statistical significance at the 10,5 and 1 percent levels, respectively. 
Table 4 Regression results after removing the current solvency adequacy ratio

\begin{tabular}{|c|c|c|c|c|c|c|}
\hline & \multicolumn{3}{|c|}{$t+1=2012$} & \multicolumn{3}{|c|}{$t+1=2013$} \\
\hline & Coe. & S.E. & & Coe. & S.E. & \\
\hline $\mathrm{X} 2$ & -0.310 & 0.071 & $* * *$ & -0.292 & 0.074 & $* * *$ \\
\hline $\mathrm{X} 3$ & -0.304 & 0.595 & & -1.301 & 0.554 & $* *$ \\
\hline $\mathrm{X} 4$ & 0.004 & 0.004 & & -0.036 & 0.100 & \\
\hline $\mathrm{X} 5$ & 0.625 & 0.621 & & 0.025 & 0.301 & \\
\hline X6 & 4.288 & 2.548 & $*$ & 2.248 & 2.502 & \\
\hline $\mathrm{X} 7$ & -0.063 & 0.045 & & -0.008 & 0.029 & \\
\hline $\mathrm{X} 8$ & -0.023 & 0.045 & & 0.021 & 0.102 & \\
\hline $\mathrm{R} 2$ & \multicolumn{3}{|c|}{0.481} & \multicolumn{3}{|c|}{0.421} \\
\hline \multirow[t]{3}{*}{ Adjusted R2 } & \multicolumn{3}{|c|}{0.383} & \multicolumn{3}{|c|}{0.322} \\
\hline & \multicolumn{3}{|c|}{$t+1=2014$} & \multicolumn{3}{|c|}{$t+1=2015$} \\
\hline & Coe. & S.E. & & Coe. & S.E. & \\
\hline $\mathrm{X} 2$ & -0.297 & 0.063 & $* * *$ & -0.215 & 0.056 & $* * *$ \\
\hline $\mathrm{X} 3$ & -0.903 & 0.523 & $*$ & -1.219 & 0.478 & $* *$ \\
\hline $\mathrm{X} 4$ & -0.163 & 0.233 & & -0.351 & 0.189 & $*$ \\
\hline $\mathrm{X} 5$ & 0.054 & 0.012 & $* * *$ & 0.161 & 0.382 & \\
\hline X6 & 5.153 & 1.498 & $* * *$ & 5.393 & 2.582 & $* *$ \\
\hline $\mathrm{X} 7$ & 0.024 & 0.020 & & -0.018 & 0.022 & \\
\hline $\mathrm{X} 8$ & 0.243 & 0.086 & $* * *$ & -0.059 & 0.092 & \\
\hline $\mathrm{R} 2$ & \multicolumn{3}{|c|}{0.565} & \multicolumn{3}{|c|}{0.494} \\
\hline Adjusted R2 & \multicolumn{3}{|c|}{0.491} & \multicolumn{3}{|c|}{0.390} \\
\hline
\end{tabular}

$*, \quad * *$ and ${ }^{* * *}$ denote statistical significance at the 10,5 and 1 percent levels, respectively.

\section{CONCLUSION}

The service life of insurance products is usually a period after the purchase of products. Therefore, from the perspective of the policyholders, it is very important to correctly evaluate the future solvency of the insurance company for the purchase decision of insurance products, and the decision of the policyholders to choose the insurance company is also very important for the operation of the insurance company.

Based on the data of 192 objects in China Property Insurance Company from 2011 to 2015, our research uses the solvency adequacy ratio defined by CIRC as the representative index of the future solvency of the insurance company, predicts the solvency of the property insurance company one year in advance, focusing on whether the two indexes of the company size and the current solvency adequacy ratio are strong and reliable, and to provide support for policyholders' insurance purchase decisions.

We find that, contrary to the conventional thought of policyholders that large companies are more solvency-guaranteed when they buy insurance, the size of companies has a negative impact on their future solvency. The reliable index to measure the future solvency of insurance companies is the current solvency adequacy rate, while the predictive model excluding the current solvency adequacy rate has much less explanatory power. When the current solvency adequacy ratio indicators are not very different, the growth of premium and the combined ratio will have a negative impact on the future solvency. Insurance companies that pay attention to the quantity of business but not to the quality of business will deteriorate their solvency in the future. 
Because the current solvency adequacy ratio is a reliable index to measure the future solvency of insurance companies, the results of this study also show that the supervision of the regulators can effectively identify the insurance companies with solvency crisis, which is conducive to early action to protect the interests of policyholders.

\section{References}

Carson, J.M., Hoyt, R.E., Evaluating the Risk of Life Insurer Insolvency: Implications from the US for the European Union. Journal of Multinational Financial Management, 2000, 10 ( 3 ) :297-314.

Chen, R., Wong, K.A., The Determinants of Financial Health of Asian Insurance Companies. The Journal of Risk and Insurance, 2004, 71(3): 469-499.

Rauch, J., Wende, S., Solvency Prediction for Property-Liability Insurance Companies: Evidence from the Financial Crisis. The Geneva Papers, 2015, 40: 47-65.

Zhu, B., Wu, X. and Zhang, A., Empirical analysis on the influencing factors of solvency of property insurance companies in China. Insurance Studies, 2008 (5) : 33 37.

Yuan, C., Yang, B., Interpretation of Solvency Adequacy Ratio of Insurance Companies -Empirical Evidence from 16 Insurance Companies in China. Journal of Central University of Finance \& Economics, 2014（9）: 36 54.

Zheng, L., The influencing factors of solvency of insurance companies in China. Scientific decision making, 2014 5) : 72 82.

Zhou, J., Zhao, G., Early warning research on financial deterioration of property insurance companies in China based on Logistic model. Economic Science, 2007 (3) : 113 123.

Shang, Y., Li, H., Jia, S., Study on the early warning mechanism of solvency of China's property insurance companies - Empirical analysis based on ordered response model. Zhejiang Finance, 2011 (10) : 62 65.

Lv, C., Zhou, X., Yang, J., Prediction study on deterioration of solvency of insurance companies. Journal of Finance and Economics, 2006 (10): 151 153.

Hair, J.F., Black, W.C., Babin, B.J., Anderson, R.E. and Tatham, R.L., Multivariate Data Analysis, 6th edn, Upper Saddle River, NJ: Pearson Pretice-Hall.

Kramer, B. An Ordered Logit Model for the Evaluation of Dutch Non-life Insurance Companies. De Economist, 1996, 144(1): 79-91. 